\title{
PERILAKU PENGGUNAAN ALAT PELINDUNG DIRI PADA PETUGAS UNIT TRANFUSI DARAH DI RUMAH SAKIT UMUM DAERAH WILAYAH BARAT SELATAN ACEH
}

\author{
Behavior of the Use of Personal Protective Equipment in Officers of the Blood Transfusion \\ Unit at the Regional General Hospital of the South West Region of Aceh \\ Ishalyadi $^{1}$ \\ ${ }^{1}$ Fakultas Kesehatan Masyarakat Universitas Teuku Umar \\ *(Ishalyadi@utu.ac.id)
}

\begin{abstract}
ABSTRAK
Risiko bagi petugas yang bekerja di Unit Tranfusi Darah adalah terjadi kecelakaan akibat kerja dan tertularnya penyakit akibat kerja, seperti tertular virus HIV, Hepatitis B, maupun penyakit menular lainnya. Untuk mencegah risiko tersebut petugas harus memakai Alat Pelindung Diri. Alat Pelindung Diri terdiri dari sarung tangan, baju pelindung, penutup kepala, masker, kaca mata pelindung dan sepatu merupakan keharusan bagi petugas yang bekerja di Unit Tranfusi Darah. Penelitian ini bertujuan menganalisis perilaku penggunaan Alat Pelindung Diri oleh petugas Unit Tranfusi Darah di Rumah Sakit Umum Daerah Barat Selatan Aceh. Jenis penelitian ini menggunakan pendekatan kuantitatif dengan rancangan studi cross sectional dengan besar sampel adalah total populasi yaitu 35 orang. Analisis data secara univariat, bivariat dengan chi square. Penelitian menunjukkan bahwa pada variabel terdapat pengaruh terhadap perilaku penggunaan Alat Pelindung Diri pada variabel Pengetahuan $(\mathrm{p}=0,007)$, varibel masa krja $(\mathrm{p}=0,030)$ dan variabel hambatan $(\mathrm{p}=0,002)$. Diharapkan kepada petugas Unit Tranfusi Darah agar lebih meningkatkan pengetahuan, dan bagi pihak Rumah Sakit agar menyediakan Alat Pelindung Diri yang lengkap dan memenusi standar keselamatan.
\end{abstract}

Kata Kunci : perilaku, penggunaan APD, petugas UTD, Rumah Sakit

\begin{abstract}
Risks for officers working in the Blood Transfusion Unit are accidents caused by work and contracting work-related diseases, such as contracting the HIV, Hepatitis B and other infectious diseases. To prevent this risk, officers must use Personal Protective Equipment. Personal protective equipment consisting of gloves, protective clothing, headgear, masks, protective glasses and shoes is a must for officers working in the Blood Transfusion Unit. This study aims to analyze the behavior of the use of Personal Protective Equipment by officers of the Blood Transfusion Unit in the South West Regional General Hospital of Aceh. This type of research uses a quantitative approach with a cross sectional study design with a sample size is a total population of 35 people. Univariate, bivariate data analysis with chi square. Research shows that in the variable there is an influence on the behavior of the use of Personal Protective Equipment on Knowledge variables $(p=0.007)$, the time period variable $(p=$ $0.030)$ and the obstacle variable $(p=0.002)$. It is expected that officers of the Blood Transfusion Unit will further enhance their knowledge, and for the Hospital to provide a complete Personal Protective Equipment and manage safety standards.
\end{abstract}

Keywords: behavior, use of PPE, UTD officer, Hospital 


\section{PENDAHULUAN}

Program Keselamatan dan Kesehatan Kerja (K3) telah lama diterapkan di dunia internasional dalam berbagai sektor indrustri, kecuali di sektor kesehatan. Perkembangan Kesehatan dan Keselamatan Kerja Rumah Sakit (K3RS) tertinggal karena masih terfokus pada kegiatan kuratif, bukan preventif. Fokus pelayanan bagi pasien, tenaga profesi kesehatan di bidang K3 masih terbatas sehingga keselamatan dan kesehatan bagi pasien maupun kesehatan pekerja dalam memberikan pelayanan kesehatan sering terlupakan, hal ini dikarenakan organisasi kesehatan masih menganggap bahwa pemberi pelayanan kesehatan pasti telah melindungi diri dalam bekerja (Kepmenkes, 2010)

Penerapan K3 di Rumah Sakit bertujuan untuk meningkatkan keamanan dan menghindari dari kecelakaan disaat bekerja (Tarwaka, 2014)

Kecelakaan ditempat kerja dapat dipengaruhi oleh berbagai faktor yaitu: lingkungan kerja, kegagalan komponen dan manusia. Dari berbagai penyebab kecelakaan, perilaku manusia adalah unsur yang memiliki peranan penting dalam terjadinya kecelakaan atau kejadiaan yang tidak diharapkan (Ramli, S, 2011)

Setiap aktifitas pekerjaan tentunya tidak terlepas dari sebuah risiko (Salawati L , 2009). Perbedaannya adalah pada tingkat penyebaran risiko tersebut terhadap pekerja. Berkerja di
Unit Tranfusi Darah juga tidak terlepas dari risiko. Seperti, tertusuk jarum, penularan virus hepatitis, dermatitis, HIV, infeksi dan gangguan pernafasan dari pendonor.

Unit Tranfusi Darah yang disingkat dengan UTD merupakan proses pengambilan darah dari masyarakat umum atau disebut pendonor, dimana petugas tidak melakukan pemeriksaan awal terhadap status darah atau kesehatan pendonor. Apakah pendonor memiliki riwayat penyakit yang dapat ditularkan kepada petugas seperti Hepatitis, HIV, ataupun pendonor tidak menjadi ancaman bagi petugas. Ketidaktahuan status darah atau riwayat kesehatan pendonor memberikan risiko terhadap petugas yang bekerja di bagian UTD. Untuk mencegah risiko ditempat kerja petugas harus memperhatikan hirarki pencegahan risiko. Hirarki tersebut adalah; 1). Eliminasi; 2). Subtitusi; 3). Administrasi; 4). Alat pelindung diri. Dari ke empat hirarki tersebut, pemakaian APD merupakan pengendalian yang paling efektif di laksanakan pada pekerja di UTD. Hal ini dikarekan proses kegiatan pekerja di UTD tidak bisa dihindari dari kontak langsung dengan pendonor. Anjuran pemakaian APD saat melakukan tranfusi darah juga terdapat pada permenkes 91 tahun 2015 tentang standar pelayanan tranfusi darah (Silaban G, 2016 )

Pemakaian APD disaat bekerja seperti, sarung tangan, baju pelindung, penutup kepala, masker, kaca mata pelindung dan sepatu sepatu 
merupakan keharusan bagi petugas yang bekerja di UTD (Direktorat Bina Pelayanan Publik, 2009). Hal ini dilakukan oleh kesadaran bahwa penyebaran penyakit infeksi melalui medium darah, sehingga pencegahan yang paling utama adalah dengan cara memperkecil tingkat kejadian kontak darah antara petugas dengan pendonor. Penggunaan APD oleh petugas merupakan salah satu upaya dalam pencegahan terjadinya penularan penyakit dari pendonor kepada petugas dan sebaliknya, sehingga penggunaan APD berhubungan langsung dengan penularan penyakit infeksi.

\section{International Labour Organization}

(ILO) mencatat bahwa setiap 15 detik seorang pekerja meninggal dunia karena kecelakaan kerja serta sebanyak 160 pekerja mengalami sakit akibat kerja. Menurut data Jamsostek tahun 2013, angka kecelakaan kerja mencapai 103.285 kasus dari 12,4 juta jumlah pekerja peserta Jamsostek. Jumlah kasus kecelakaan akibat kerja tahun 2011-2014 yang paling tinggi pada 2013 yaitu 35.917 kasus kecelakaan kerja (tahun $2011=9.891$; tahun $2012=21.735 ;$ tahun $2014=24.910$ )

Data awal di salah satu Rumah Sakit Daerah Wilayah Selatan Aceh, yaitu Rumah Sakit Daerah "X". Dari 8 orang pekerja di ruang UTD terdapat $38 \%$ yang menggunakan APD (hanscoon, masker, dan sepatu) dan $62 \%$ tidak memakai APD lengkap. Data tersebut bertolak belakang dengan permenkes no 91 tahun 2015 yang mengwajibkan pemakaian APD di setiap kegiatan tranfusi darah.

\section{METODE}

Penelitian ini menggunakan pendekatan kuantitatif dengan rancangan studi cross sectional dengan besar sampel adalah total populasi yaitu 35 orang. Analisis data secara univariat, bivariat dengan uji chi square.

\section{HASIL}

\section{Analisa Univariat}

\section{Pengetahuan}

Tabel 1. Distribusi Frekuensi Berdasarkan Pengetahuan Responden Terhadap Perilaku Pemakaian Alat Pelindung Diri

\begin{tabular}{llll}
\hline No & Pengetahuan & Frekuensi & \% \\
\hline 1 & Kurang & 18 & 51,4 \\
\hline 2 & Baik & 17 & 48,6 \\
\hline Total & 35 & 100 \\
\hline
\end{tabular}

Sumber : Data Primer 2017 


\section{Masa Kerja}

Tabel 2. Distribusi Frekuensi Berdasarkan Masa Kerja Responden Terhadap Perilaku Pemakaian Alat Pelindung Diri

\begin{tabular}{llll}
\hline No & Masa Kerja & Frekuensi & \% \\
\hline 1 & Baru & 23 & 65,7 \\
\hline 2 & Lama & 12 & 34,3 \\
\hline Total & 35 & 100 \\
\hline
\end{tabular}

Sumber : Data Primer 2017

Hambatan

Tabel 3. Distribusi Frekuensi Berdasarkan Hambatan Responden Terhadap Perilaku Pemakaian Alat Pelindung Diri

\begin{tabular}{llll}
\hline No & Hambatan & Frekuensi & \% \\
\hline 1 & Rendah & 19 & 54,3 \\
\hline 2 & Tinggi & 16 & 45,7 \\
\hline Total & 35 & 100 \\
\hline
\end{tabular}

Sumber : Data Primer 2017

Bivariat

Pengaruh Pengetahuan terhadap Perilaku Penggunaan Alat Pelindung Diri

Tabel 4. Faktor Pengetahuan Yang Mempengaruhi Perilaku Penggunaan

Alat Pelindung Diri

\begin{tabular}{|c|c|c|c|c|c|c|c|c|}
\hline \multirow{3}{*}{ No } & \multirow{3}{*}{ Pengetahuan } & \multicolumn{4}{|c|}{$\begin{array}{l}\text { Perilaku Penggunaan } \\
\text { Alat Pelindung Diri }\end{array}$} & \multirow{2}{*}{\multicolumn{2}{|c|}{ Total }} & \multirow{3}{*}{ p.value } \\
\hline & & \multicolumn{2}{|c|}{ Kurang } & \multicolumn{2}{|c|}{ Baik } & & & \\
\hline & & $\mathrm{N}$ & $\%$ & $\mathrm{n}$ & $\%$ & $\mathrm{n}$ & $\%$ & \\
\hline 1 & Kurang & 14 & 40,0 & 4 & 11,4 & 18 & 51,4 & \\
\hline 2 & Baik & 5 & 14,3 & 12 & 34,5 & 22 & 46,6 & 0,007 \\
\hline Total & & 19 & 54,3 & 16 & 45,7 & 35 & 100,0 & \\
\hline
\end{tabular}

Sumber : Data Primer 2017

Pengaruh Masa Kerja Terhadap Perilaku Penggunaan Alat Pelindung Diri

Tabel 5. Faktor Masa Kerja Yang Mempengaruhi Perilaku Penggunaan

Alat Pelindung Diri

\begin{tabular}{|c|c|c|c|c|c|c|c|c|}
\hline \multirow{3}{*}{ No } & \multirow{3}{*}{ Masa Kerja } & \multicolumn{4}{|c|}{$\begin{array}{l}\text { Perilaku Penggunaan } \\
\text { Alat Pelindung Diri }\end{array}$} & \multirow{2}{*}{\multicolumn{2}{|c|}{ Total }} & \multirow{3}{*}{ p.value } \\
\hline & & \multicolumn{2}{|c|}{ Kurang } & \multicolumn{2}{|c|}{ Baik } & & & \\
\hline & & $\mathrm{N}$ & $\%$ & $\mathrm{n}$ & $\%$ & $\mathrm{n}$ & $\%$ & \\
\hline 1 & Baru & 16 & 45,7 & 7 & 20,0 & 23 & 65,7 & \\
\hline 2 & Lama & 3 & 8,6 & 9 & 25,7 & 22 & 34,3 & 0,030 \\
\hline \multicolumn{2}{|c|}{ Total } & 19 & 54,3 & 16 & 45,7 & 35 & 100,0 & \\
\hline
\end{tabular}

Sumber : Data Primer 2017 


\section{Pengaruh Hambatan Terhadap Perilaku Penggunaan Alat Pelindung Diri Tabel 6. Faktor Masa Kerja Yang Mempengaruhi Perilaku Penggunaan Alat Pelindung Diri}

\begin{tabular}{|c|c|c|c|c|c|c|c|c|}
\hline \multirow{3}{*}{ No } & \multirow{3}{*}{ Hambatan } & \multicolumn{4}{|c|}{$\begin{array}{l}\text { Perilaku Penggunaan } \\
\text { Alat Pelindung Diri }\end{array}$} & \multirow{2}{*}{\multicolumn{2}{|c|}{ Total }} & \multirow{3}{*}{ p.value } \\
\hline & & \multicolumn{2}{|c|}{ Kurang } & \multicolumn{2}{|c|}{ Baik } & & & \\
\hline & & $\mathrm{N}$ & $\%$ & $\mathrm{n}$ & $\%$ & $\mathrm{n}$ & $\%$ & \\
\hline 1 & Baru & 15 & 42,9 & 4 & 11,4 & 19 & 54,3 & \\
\hline 2 & Lama & 4 & 11,4 & 12 & 34,3 & 16 & 45,7 & 0,002 \\
\hline \multicolumn{2}{|c|}{ Total } & 19 & 54,3 & 16 & 45,7 & 35 & 100,0 & \\
\hline
\end{tabular}

Sumber : Data Primer 2017

\section{PEMBAHASAN}

\section{Pengaruh Pengetahuan terhadap Perilaku}

\section{Penggunaan Alat Pelindung Diri}

Berdasakan hasil penelitian ini diketahui bahwa terdapat pengaruh anatara variabel pengetahuan dengan perilaku penggunaan Alat Pelindung Diri petugas di Rumah Sakit Barat Selatan Aceh dengan hasil uji chi square didapat nilai $\mathrm{p}_{\text {value }}=0,007$ lebih besar dari dari $\alpha=0,05\left(\mathrm{p}_{\text {value }}=0,05>\mathrm{p}_{\text {value }}=0,007\right)$. Dari hasil tersbut dapat kita ketahui bahwa terdapat pengaruh antara variebel pengetahuan dengan perilaku penggunaan Alat Pelindung Diri pada petugas unit Tranfusi Darah di Rumah Sakit Umum Daerah barat Selatan Aceh.

Menurut penelitian yang dilakukan oleh aditya dan pratama didapatkan hubungan kuat antara pengetahuan dengan perilaku unsafe action. Semakin rendahnya pengetahuan seseorang maka semikin tinggi pula seseorang dalam berperilaku tindakan tidak aman (Pratama AK, 2015 )

Seseorang tanpa pengetahuan tidak akan mempunyai dasar dalam pengambilan keputusan dan menentukan tindakan terhadap masalah yang dihadapi. Faktor yang mempengaruhi pengetahuan seseorang yaitu faktor internal dan faktor eksternal.

Pengetahuan tentang kesehatan adalah segala sesuatu yang mencakup apa yang diketahui oleh seseorang terhadap cara-cara memelihara kesehatan dirinya. Pengetahuan tentang cara-cara memelihara kesehatan ini meliputi, diantaranya pengetahuan untuk menghindari kecelakaan baik kecelakaan rumah tangga, kecelakaan lalu lintas, tempattempat umum, dan seterusnya. Sehingga pengetahuan responden yang baik cenderung berperilaku baik terhadap penggunaan APD. Peningkatan pengetahuan tentu tidak selalu menjamin terhadap penyebab perubahan suatu perilaku seseorang, akan tetapi pengetahuan sangat penting diberikan sebelum individu melakukan suatu tindakan. Misalnya pelatihan, seminar tentang kesehatan dan keslamatan kerja dan lain-lain. Tindakan akan sesuai dengan pengetahuan apabila individu menerima isyarat yang cukup kuat untuk memotivasi individu untuk bertindak sesuai dengan pengetahuannya. 


\section{Pengaruh Masa Kerja Terhadap Perilaku Penggunaan Alat Pelindung Diri}

Berdasakan hasil penelitian ini diketahui bahwa terdapat pengaruh anatara variabel masa kerja dengan perilaku penggunaan Alat Pelindung Diri petugas di Rumah Sakit Barat Selatan Aceh dengan hasil uji chi square didapat nilai $\mathrm{p}_{\text {value }}=0,030$ lebih besar dari dari $\alpha=0,05\left(\mathrm{p}_{\text {value }}=0,05>\mathrm{p}_{\text {value }}=0,030\right)$. Dari hasil tersbut dapat kita ketahui bahwa terdapat pengaruh antara variebel masa kerja dengan perilaku penggunaan Alat Pelindung Diri pada petugas unit Tranfusi Darah di Rumah Sakit Umum Daerah barat Selatan Aceh.

Masa kerja dihitung dari lamanya bekerja seseorang, berkaitan erat dengan pengalaman yang telah didapat selama menjalankan tugasnya. Pengalaman seseorang dalam melakukan pekerjaanya secara terus menerus dan lama akan meningkatkan kedewasaan teknisnyaMasa kerja dihitung dari lamanya bekerja seseorang, berkaitan erat dengan pengalaman yang telah didapat selama menjalankan tugasnya. Pengalaman seseorang dalam melakukan pekerjaanya secara terus menerus dan lama akan meningkatkan kedewasaan teknisnya. Hal ini juga sejalan dengan penelitian yang dilakukan oleh Saputra bahwa ada hubungan antara masa kerja dengan penggunaan alat pelindung diri (Saputra R, 2016 )

\section{Pengaruh Hambatan Terhadap Perilaku Penggunaan Alat Pelindung Diri}

Berdasakan hasil penelitian ini diketahui bahwa terdapat pengaruh anatara variabel masa kerja dengan perilaku penggunaan Alat Pelindung Diri petugas di Rumah Sakit Barat Selatan Aceh dengan hasil uji chi square didapat nilai $\mathrm{p}_{\text {value }}=0,002$ lebih besar dari dari $\alpha=0,05\left(\mathrm{p}_{\text {value }}=0,05>\mathrm{p}_{\text {value }}=0,002\right)$. Dari hasil tersbut dapat kita ketahui bahwa terdapat pengaruh antara variebel hambatan dengan perilaku penggunaan Alat Pelindung Diri pada petugas unit Tranfusi Darah di Rumah Sakit Umum Daerah barat Selatan Aceh.

Hambatan responden dapat berasal dari internal dan eksternal. Hambatan dari internal bisa terjadi akibat persepsi seseorang terhadap penggunaan APD. Hambatan yang dirasakan oleh responden dalam menerapkan perilaku aman seperti, persepsi diri, keyakinan dan tidak tersedianya APD tentu akan berpengaruh dalam berperilaku aman. Hal ini berhubungan dengan proses evaluasi individu sendiri atas hambatan yang dihadapi untuk mengadopsi perilaku baru. Persepsi tentang hambatan yang akan dirasakan merupakan unsur yang signifikan dalam menentukan apakah terjadi perubahan perilaku atau tidak. Berkaitan dengan perilaku baru seseorang harus percaya bahwa konsekuensi mempertahankan perilaku lama lebih buruk daripada melanjutkan perilaku baru, maka hambatan harus diatasi sebaik mungkin, seperti ketersediaan APD, dukungan pimpinanan dan lain lain (Priyoto, 
2014). Semakin lengkap APD yang tersedia maka semakin baik perilaku penggunaan APD (Noegroho Boedijowono, 2011). Di Rumah Sakit Umum Daerah Barat Selatan Aceh hanya tersedia sarung tangan, masker dan gaun pelindung, sedangkan kaca mata, sepatu dan topi penutup tidak tersedia sama sekali.

Selain dari ketersediaan APD yang harus dipenuhi faktor kepemimpinan juga berperan dalam meningkatkan motivasi dalam berperilaku aman. Hasil analisis faktor konfirmatori mengidentifikasi tiga dimensi utama kepemimpinan keselamatan, yang diukur pada skala kepemimpinan keselamatan: safety motivasi, kebijakan keamanan dan masalah keamanan. Hasil penelitian menunjukkan bahwa motivasi mempengaruhi perilaku keamanan dan keselamatan diri mereka, seperti kepatuhan keselamatan dan partisipasi keselamatan, dan dimensi kebijakan keselamatan dari pimpinan juga memiliki efek positif pada keselamatan partisipasi. Selanjutnya Darmawan menunjukkan bahwa ada hubungan antara kelengkapan APD pada pekerja dengan kejadian kecelakaan kerja. Ketersediaan dan penggunaan APD yang tepat akan pengaruh dalam mengurangi risiko terhadap petugas di UTD. Teori lain menyatakan bahwa persyaratan umum

\section{DAFTAR PUSTAKA}

1. Kepmenkes RI No. 1087/MENKES/SK/VIII?2010. 2010. Kesehatan dan Keselamatan Kerja di penyediaan APD yang efektif harus sesuai dengan bahaya yang dihadapi, terbuat dari material yang akan tahan terhadap bahaya tersebut, cocok bagi orang yang akan menggunakannya, tidak mengganggu kerja operator yang sedang bertugas, memiliki konstruksi yang sangat kuat, tidak mengganggu APD lain yang sedang dipakai secara bersamaan, tidak meningkatkan risiko pemakaiannya (Darmawan A Dkk, 2014 ).

\section{KESIMPULAN}

Terdapat pengaruh yang signifikan antara variabel pengetahuan, masa kerja dan hambatan dengan perilaku penggunaan Alat Pelindung Diri pada Petugas Unit Tranfusi darah di Rumah Sakit Umum Daerah Barat Selatan Aceh

\section{SARAN}

Diharapkan kepada petugas untuk meningkatkan pengetahuan yang akan mempengaruhi terhadap perilaku penguanaan Alat pelindung Diri. Bagi pihak Rumah Sakit Umum Daerah Barat Selatan Aceh agar menyediakan Alat Pelindung Diri yang baik dan aman dan bagi peneliti selanjutnya agar dapat meneliti tentang persepsi peutugas Unit Tranfusi Darah terhadap pemakaian Alat Pelindung Diri saat bekerja.

\section{Rumah Sakit. Jakarta}

2. Tarwaka. 2014. Keselamatan Dan Kesehatan Kerja; Manajemen dan Implementasi K3 di Tempat Kerja. 
Harapan Press. Surakarta

3. Ramli S. 2011 Pedoman Praktis Manajemen Resiko. Dian Rakyat. Jakarta

4. Salawati L. 2009. Hubungan Perilaku, Manajemen Keselamatan Dan Kesehatan Kerja Dengan Terjadinya Kecelakaan Kerja Di Laboratorium Patologi Klinik Rumah.

5. Silaban G. 2016 Keselamatan Dan Kesehatan Kerja. Prima Jaya. Medan

6. Direktorat Bina Pelayanan Publik. 2015. Pedoman Pengelolaan Unit Tranfusi Darah. Direktorat Bina Pelayanan Publik. Jakarta

7. Pratama AK. 2015. Hubungan Karakteristik Pekerja Dengan Unsafe Action Pada Tenaga Kerja Bongkar Muat Di Pt . Terminal Petikemas Indones J Occup Saf Heal. 4(1):64-73. Surabaya
8. Saputra R, Hariyono W. 2016. Hubungan Masa Kerja dan Penggunaan Alat Pelindung Diri Dengan Keluhan Gangguan Saluran Pernafasan Pada Karyawan di PT. Madubaru Semin Nas IENACO. 2016;58-63. Bantul

9. Priyoto. 2014Teori Sikap dan Perilaku Dalam Kesehatan. Nuha Medika. Yogyakarta

10. Noegroho Boedijowono. 2011. Pengantar statistik ekonomi dan perusahaan. UPP AMP YKPN. Yogyakarta

11. Darmawan A Dkk. 2014. Kelengkapan Alat Pelindung Diri , Lama Pembagian Waktu Kerja , dan Pemahaman Pekerja Tentang Briefing dengan Kecelakaan Kerja di Pabrik Kelapa Sawit PT . Bukit Barisan Indah Prima Jambi. JMJ.18-26. 